\title{
CHANGES IN SMOKING HABITS, 1959-1963
}

BY

\section{F. PYGOTT}

Radiologist, Central Middlesex Hospikal

Early in 1959 it was decided to carry out an inquiry into the smoking habits of 10,000 consecutive persons attending the mass $x$-ray section of the $X$-ray Department at the Central Middlesex Hospital. The information was obtained by the receiving clerk as a part of normal documentation and the answers given were not questioned by her, in order not to give the examinee an impression that this was other than a normal routine. It was decided to repeat the inquiry again in the same period of 1963, using precisely the same method to see whether there had been any change in smoking habits as a result of the increase in the anti-smoking campaign and the report of the Royal College of Physicians on smoking and lung cancer.

On inquiry both in 1959 and in 1963, it was found that very few examinees smoked cigarettes and pipe with equal enjoyment; if they smoked both they were predominately smokers of one or another. If they were mainly pipe smokers and smoked only the odd cigarette, they were classified as pipe smokers, and their cigarette consumption disregarded. If they were mainly cigarette smokers but also smoked an ounce or more of tobacco as pipe tobacco weekly, they were classified as cigarette smokers, and credited with smoking an extra twenty cigarettes a week per ounce of pipe tobacco. In fact, this adjustment was found to affect the number of cigarettes credited daily to only a very small proportion of the total number of smokers.

The two series show a very similar scatter of both age and sex. Thus, in 1959 there were 4,828 men and 5,172 women and in $1963,4,845$ men and 5,155 women. Only in the 15 to 19-year-old women was there a difference of more than 200 persons in the age break-down between the two series, and in nearly all other groups the differences between the two series were of the order of fifty persons in totals of between 600 and just over 1,000 in all but the groups over 65 years of age.

\section{Smoking Habits of Men 1959 and 1963}

The smoking habits of men in the two years 1959 and 1963 are shown in Table I. In both years the proportion of smokers was least in the youngest group, 15 to 19 years of age, with peaks at ages 33 to 44 and 45 to 64 . Thereafter, there was a small

TABLE I

SMOKING HABITS OF MEN AND WOMEN, 1959 AND 1963, BY AGE GROUP

\begin{tabular}{|c|c|c|c|c|c|c|c|c|c|}
\hline \multicolumn{2}{|c|}{ Sex } & \multicolumn{4}{|c|}{ Men } & \multicolumn{4}{|c|}{ Women } \\
\hline \multirow{2}{*}{ Year } & \multirow{2}{*}{$\begin{array}{c}\text { Age } \\
\text { Group } \\
\text { (yrs) }\end{array}$} & \multirow{2}{*}{$\begin{array}{c}\text { Total } \\
\text { No. of } \\
\text { Men }\end{array}$} & \multirow{2}{*}{$\begin{array}{l}\text { Per cent. } \\
\text { Non- } \\
\text { Smokers }\end{array}$} & \multicolumn{2}{|c|}{ Per cent. Smokers } & \multirow{2}{*}{$\begin{array}{c}\text { Per cent. } \\
\text { All } \\
\text { Smokers }\end{array}$} & \multirow{2}{*}{$\begin{array}{c}\text { Total } \\
\text { No. of } \\
\text { Women }\end{array}$} & \multirow{2}{*}{$\begin{array}{l}\text { Per cent. } \\
\text { Non- } \\
\text { Smokers }\end{array}$} & \multirow{2}{*}{$\begin{array}{l}\text { Per cent. } \\
\text { Cigarett } \\
\text { Smokers }\end{array}$} \\
\hline & & & & Cigarette & Pipe & & & & \\
\hline 1959 & $\begin{array}{c}15-19 \\
20-24 \\
25-34 \\
35-44 \\
45-64 \\
65+\end{array}$ & $\begin{array}{r}585 \\
651 \\
1,026 \\
829 \\
1,491 \\
246\end{array}$ & $\begin{array}{l}43 \\
34 \\
34 \\
22 \\
22 \\
28\end{array}$ & $\begin{array}{l}56 \\
65 \\
62 \\
73 \\
71 \\
62\end{array}$ & $\begin{array}{r}1 \\
1 \\
4 \\
5 \\
7 \\
10\end{array}$ & $\begin{array}{l}57 \\
66 \\
66 \\
78 \\
78 \\
72\end{array}$ & $\begin{array}{r}767 \\
950 \\
1,249 \\
805 \\
1,241 \\
160\end{array}$ & $\begin{array}{l}66 \\
58 \\
56 \\
41 \\
59 \\
74\end{array}$ & $\begin{array}{l}34 \\
42 \\
44 \\
59 \\
41 \\
26\end{array}$ \\
\hline 1963 & $\begin{array}{c}15-19 \\
20-24 \\
25-34 \\
35-44 \\
45-64 \\
65+\end{array}$ & $\begin{array}{r}715 \\
654 \\
979 \\
856 \\
1,463 \\
178\end{array}$ & $\begin{array}{l}47 \\
38 \\
33 \\
25 \\
24 \\
27\end{array}$ & $\begin{array}{l}52 \\
58 \\
61 \\
62 \\
60 \\
45\end{array}$ & $\begin{array}{r}1 \\
4 \\
6 \\
13 \\
16 \\
28\end{array}$ & $\begin{array}{l}53 \\
62 \\
67 \\
75 \\
76 \\
73\end{array}$ & $\begin{array}{r}974 \\
962 \\
1,133 \\
827 \\
1,113 \\
146\end{array}$ & $\begin{array}{l}63 \\
61 \\
61 \\
49 \\
53 \\
78\end{array}$ & $\begin{array}{l}37 \\
39 \\
39 \\
51 \\
47 \\
22\end{array}$ \\
\hline
\end{tabular}


decline in the proportion of smokers probably influenced by financial changes on retirement. Considering cigarette and pipe smokers separately, the trend was somewhat different. Over half the young men aged 15 to 19 were cigarette smokers and the proportion increased with age, except in the oldest group where there was a decline. On the other hand, a very small proportion of those aged 15 to 19 were pipe smokers, and this proportion increased steadily to reach peak levels in the oldest group, 65 years and over.

The chief contrasts between the pattern in 1959 and in 1963 are that the proportion of pipe to cigarette smokers is greater in the later years, particularly among older men. Taking cigarette and pipe smokers together, the proportion of smokers to non-smokers had not changed much between the two years.

SMOKING Habits OF WoMEN IN 1959 AND 1963

As might be expected, the proportion of smokers amongst women was less at each age than among men (Table I). Among those aged 15 to 19 years, about one-third were smokers and the proportion increased in successive age groups to reach a peak in both years at age 35 to 44 . Thereafter there was a decline, so that among women 65 years and over there was the smallest proportion of smokers. The proportion of smokers between the ages of 20 and 44 and at 65 years and over was less in 1963 than in the earlier year, but at 15 to 19 and 45 to 64 years it was greater. At no age had the proportion changed much and in general the pattern was similar in both years.

\section{Amount SMOKed}

\section{(a) Cigarette Smokers}

In both years over half the men aged 15 to 19 smoked less than ten cigarettes a day (Table II). Older men smoked rather more and, except for those 65 years and over in 1959, well over half smoked ten or more a day. In each age group the amount smoked was greater in 1963 than in 1959.

Among women, as in men, the amount smoked was least in those aged 15 to 19 and 65 years and over (Table II). Between 1959 and 1963, there was an increase in the proportion of heavier smokers, although the general levels were considerably lower than those for men.

\section{(b) Pipe Smokers}

The amount of tobacco smoked was least in those aged 15 to 19 years, in the majority of whom it was less than $2 \mathrm{oz}$. a week (Table III, opposite). In older age groups the amount consumed was greater and the majority of pipe smokers consumed more than 2 oz. per week. There was a slight fall in consumption in the oldest group, 65 years and over.

In general the main change between 1963 and 1959 was an increase in the amount smoked, most pronounced for the younger men.

TABLE II

NUMBER OF CIGARETTES SMOKED BY MEN AND WOMEN, 1959 AND 1963, BY AGE GROUP

\begin{tabular}{|c|c|c|c|c|c|c|c|c|c|}
\hline \multirow{2}{*}{ Sex } & \multirow{2}{*}{ Year } & \multirow{2}{*}{$\underset{\text { (yrs) }}{\text { Age }}$} & \multirow{2}{*}{$\begin{array}{c}\text { Total } \\
\text { No. of } \\
\text { Cigarette } \\
\text { Smokers }\end{array}$} & \multicolumn{5}{|c|}{ No. of Cigarettes Smoked Daily (per cent.) } & \multirow{2}{*}{$\begin{array}{c}\text { Average } \\
\text { No. of } \\
\text { Cigarettes } \\
\text { Smoked } \\
\text { Daily }\end{array}$} \\
\hline & & & & $0-4$ & $5-9$ & $10-19$ & $20-29$ & $30+$ & \\
\hline \multirow{2}{*}{ Men } & 1959 & $\begin{array}{c}15-19 \\
20-24 \\
25-34 \\
35-44 \\
45-64 \\
65+\end{array}$ & $\begin{array}{r}330 \\
422 \\
640 \\
604 \\
1,060 \\
153\end{array}$ & $\begin{array}{l}28 \\
15 \\
14 \\
10 \\
11 \\
23\end{array}$ & $\begin{array}{l}39 \\
42 \\
29 \\
23 \\
26 \\
35\end{array}$ & $\begin{array}{l}30 \\
37 \\
47 \\
51 \\
47 \\
38\end{array}$ & $\begin{array}{r}2 \\
4 \\
7 \\
12 \\
11 \\
2\end{array}$ & $\begin{array}{l}1 \\
2 \\
3 \\
4 \\
5 \\
2\end{array}$ & $\begin{array}{r}8.4 \\
9.7 \\
11.7 \\
13.2 \\
12.9 \\
9.3\end{array}$ \\
\hline & 1963 & $\begin{array}{c}15-19 \\
20-24 \\
25-34 \\
35-44 \\
45-64 \\
65+\end{array}$ & $\begin{array}{r}375 \\
384 \\
592 \\
534 \\
871 \\
80\end{array}$ & $\begin{array}{r}25 \\
9 \\
10 \\
7 \\
10 \\
14\end{array}$ & $\begin{array}{l}31 \\
17 \\
19 \\
16 \\
16 \\
15\end{array}$ & $\begin{array}{l}38 \\
60 \\
54 \\
56 \\
49 \\
55\end{array}$ & $\begin{array}{r}5 \\
10 \\
11 \\
15 \\
17 \\
12\end{array}$ & $\begin{array}{l}1 \\
4 \\
6 \\
6 \\
8 \\
4\end{array}$ & $\begin{array}{r}9.7 \\
13.7 \\
13.9 \\
14.9 \\
15.9 \\
12.2\end{array}$ \\
\hline \multirow{2}{*}{ Women } & 1959 & $\begin{array}{c}15-19 \\
20-24 \\
25-34 \\
35-44 \\
45-64 \\
65+\end{array}$ & $\begin{array}{r}261 \\
400 \\
552 \\
473 \\
504 \\
41\end{array}$ & $\begin{array}{l}48 \\
36 \\
28 \\
23 \\
32 \\
51\end{array}$ & $\begin{array}{l}40 \\
42 \\
40 \\
40 \\
37 \\
32\end{array}$ & $\begin{array}{l}11 \\
21 \\
28 \\
32 \\
27 \\
12\end{array}$ & $\begin{array}{l}1 \\
1 \\
3 \\
4 \\
3 \\
5\end{array}$ & $\begin{array}{c}\overline{-} \\
1 \\
1 \\
-\end{array}$ & $\begin{array}{l}5.6 \\
7.0 \\
8.5 \\
9.2 \\
8.2 \\
6.2\end{array}$ \\
\hline & 1963 & $\begin{array}{c}15-19 \\
20-24 \\
25-34 \\
35-44 \\
45-64 \\
65+\end{array}$ & $\begin{array}{r}359 \\
372 \\
437 \\
423 \\
513 \\
32\end{array}$ & $\begin{array}{l}44 \\
27 \\
26 \\
18 \\
20 \\
35\end{array}$ & $\begin{array}{l}29 \\
31 \\
26 \\
29 \\
26 \\
25\end{array}$ & $\begin{array}{l}25 \\
38 \\
39 \\
44 \\
45 \\
28\end{array}$ & $\begin{array}{l}\mathbf{2} \\
\mathbf{3} \\
\mathbf{8} \\
\mathbf{8} \\
7 \\
9\end{array}$ & $\begin{array}{l}\overline{1} \\
1 \\
1 \\
2 \\
3\end{array}$ & $\begin{array}{r}7 \cdot 0 \\
9 \cdot 3 \\
10 \cdot 3 \\
11 \cdot 0 \\
11 \cdot 1 \\
9 \cdot 6\end{array}$ \\
\hline
\end{tabular}


TABLE III

NUMBER OF OUNCES OF TOBACCO SMOKED BY MEN 1959 AND 1963

\begin{tabular}{|c|c|c|c|c|c|c|c|}
\hline \multirow{2}{*}{ Year } & \multirow{2}{*}{$\begin{array}{l}\text { Age } \\
\text { Group } \\
\text { (yrs) }\end{array}$} & \multirow{2}{*}{$\begin{array}{c}\text { Total No. } \\
\text { of } \\
\text { Pipe Smokers }\end{array}$} & \multicolumn{4}{|c|}{ Ounces of Tobacco Smoked Weekly (per cent.) } & \multirow{2}{*}{$\begin{array}{c}\text { Average } \\
\text { Ounces of Tobacco } \\
\text { Smoked Weekly }\end{array}$} \\
\hline & & & -1 & $1+$ & $2-3$ & $4 \div$ & \\
\hline 1959 & $\begin{array}{c}15-19 \\
20-24 \\
25-34 \\
35-44 \\
45-64 \\
65+\end{array}$ & $\begin{array}{r}5 \\
9 \\
28 \\
44 \\
103 \\
25\end{array}$ & $\begin{array}{l}60 \\
67 \\
36 \\
18 \\
13 \\
12\end{array}$ & $\begin{array}{l}40 \\
33 \\
50 \\
20 \\
28 \\
40\end{array}$ & $\begin{array}{l}- \\
\overline{11} \\
55 \\
49 \\
44\end{array}$ & $\begin{array}{r}- \\
4 \\
7 \\
11 \\
4\end{array}$ & $\begin{array}{l}0.9 \\
0 \cdot 8 \\
1 \cdot 4 \\
2 \cdot 3 \\
2 \cdot 4 \\
2 \cdot 1\end{array}$ \\
\hline 1963 & $\begin{array}{c}15-19 \\
20-24 \\
25-34 \\
35-44 \\
45-64 \\
65+\end{array}$ & $\begin{array}{r}5 \\
20 \\
61 \\
109 \\
241 \\
50\end{array}$ & $\begin{array}{r}20 \\
5 \\
25 \\
12 \\
13 \\
18\end{array}$ & $\begin{array}{l}60 \\
30 \\
23 \\
22 \\
21 \\
18\end{array}$ & $\begin{array}{l}20 \\
65 \\
49 \\
61 \\
56 \\
52\end{array}$ & $\begin{array}{r}- \\
3 \\
5 \\
10 \\
12\end{array}$ & $\begin{array}{l}1 \cdot 6 \\
2 \cdot 4 \\
2 \cdot 1 \\
2 \cdot 4 \\
2 \cdot 4 \\
2 \cdot 4\end{array}$ \\
\hline
\end{tabular}

\section{Conclusions}

Review of the information obtained from the two series shows that there has been generally a slight decline in the proportion of smokers among the men, taking cigarette and pipe smokers together, which does not amount to more than 4 per cent. in any of the groups under the age of 65 . Over the age of 65 there was little change in smoking habit. There was a transference to pipe-smoking among men smokers, so that this is now more than twice as popular as it was in 1959. The amount of pipe tobacco smoked per head increased.

Among the men who smoke cigarettes it is clear that the consumption increased at all ages, and that heavy smoking (i.e. thirty or more daily) was more frequent from 25 years to the age of 65 than it was in 1959. Thus 97 out of a total of 2,689 men smokers between the ages of 25 and 64 in 1959 smoked thirty or more daily (3.6 per cent.) while 139 out of 2,398 did so in 1963 (5.8 per cent.). The totals who smoked forty or more daily, however, had risen from 28 to 48 in the same age range.

In the women questioned in 1963 there was a decline in the number smoking of 3 to 8 per cent. in the age groups up to 45 years, and there was an increase of 6 per cent. in the 45 to 64 age group compared with 1959. Among the women who smoked in 1963 there was a clear increase in the average number of cigarettes smoked. Out of a total of 1,529 women cigarette smokers between the ages of 25 and 65 in 1959, only ten smoked more than thirty a day ( 0.6 per cent.), but in 196321 out of 1,373 did so ( 1.5 per cent.). The totals who smoked over forty daily in the same group were none and seven respectively.

The investigation suggests that the campaign to reduce smoking has so far had a very small but definite effect in reducing the proportion of smokers in age groups of both sexes, except among the women between 45 and 65, more of whom are smoking in 1963 than in 1959. Among the remaining cigarette smokers in all age groups there is a very considerable increase in the amount smoked. The number of men pipe smokers has more than doubled in the period and now amounts to 15 per cent. of the total number of smokers. It is obvious that, if the connexion between smoking and lung cancer is accepted, the present effort to discourage smoking has had very little effect and that much more needs to be done if this disease is to be brought under control. 